\title{
Psychosocial rehabilitation and mental health (24th European Congress of Psychiatry materials review)
}

\author{
Frankova I.O. ${ }^{\mathrm{a}}$, Krasnova P.V. ${ }^{\mathrm{b}}$ \\ ${ }^{a}$ Department of psychosomatic medicine and psychotherapy, Bogomolets National Medical University, Kyiv, Ukraine \\ ${ }^{b}$ Center of psychological and psychiatric correction and rehabilitation "Personality Almaty, Kazakhstan
}

\begin{abstract}
Background. Mental illness - is a heavy burden of modern society and may be underestimated. There are several reasons: the high prevalence of this category of disorders, high level of stigmatization, treatment gap between those who are mentally ill and those will be treated. The economic crisis and the lack of resources, make psychosocial rehabilitation of mental disorders even more complicated.

Methods. This review is based on materials of the 24th Congress of the European Psychiatric Association (April 2016, Madrid), the participants of the "Eastern European Academy of the World Psychiatric Association and "Servier"company specifically for psychiatric journals of WPA Zone 10 (East European Educational WPA-Servier Academy - «EEE WPAServier Academy». The review will present materials from several symposiums: "Psychosocial rehabilitation and mental health "Overcoming the stigma of mental disorders: recent advances and initiatives,Fight stigma: a global challenge and state-of-the-art report, "Psychosocial interventions in schizophrenia».

Results. As result, we anticipate that this review will distribute and promote knowledge about high quality standards and evidence-based research and treatment methods among the modern community of mental health experts.

Conclusion. Current approach in psychosocial rehabilitation of severe mental disorders has changed significantly due to the data of evidence-based medicine, the use of effective, superior methods suggests a good outcome for a larger number of patients.
\end{abstract}

\section{1. Актуальність}

Психічні захворювання - це важка і недооцінена ноша для сучасного суспільства. Причин тому кілька: висока поширеність даної категорії розладів, низький рівень звернень за допомогою, високий рівень стигматизації. Витрати на лікування пацієнтів з психічними розладами великі, це викликано погіршенням їх рівня функціонування, раннім початком психічних порушень, більш низьким рівнем освіти, вживанням психоактивних речовин (ПАР). Економічна криза і нестача ресурсів, в широкому сенсі цього слова, роблять завдання, яке стоїть перед сучасною психіатрією, ще більш складною. Одним з варіантів розв'язання проблеми президент Європейської психіатричної асоціації (ЕПА) проф. Wolfgang Gaebel (Dusseldorf, Germany) бачить в активному залученні молодих кадрів і можливості співпраці з іншими фахівцями, які працюють в сфері охорони психічного здоров'я (клінічні психологи, соціальні працівники, молодший медичний персонал).
Ці дані він представив у вступному слові до відкриття 24-го Конгресу ЕПА під назвою: «Психіатрія в Європі: чого ми досягли і що чекає нас попереду?». Він підкреслив, що перед сучасним суспільством психіатрів стоїть завдання поширювати і просувати узгоджені стандарти якості в професійному, теоретичному, практичному навчанні молодих фахівців, і проведення досліджень, експертиз і методів лікування, заснованих на доказовій медицині.

Темі психосоціальної реабілітації на конгресі було присвячено не мало симпозіумів, пленарних лекцій i окремих доповідей. В огляді будуть детально представлені матеріали симпозіумів «Психосоціальна реабілітація та психічне здоров'я», «Долаючи стигматизацію психічних розладів: сучасні досягнення та ініціативи», «Боротьба зі стигмою: всесвітня завдання» i state-ofthe-art доповіді: «Психосоціальні інтервенцій при шизофренії Til Wykes, London, United Kingdom. 


\section{2. Стигматизація}

Одну з головних проблем у розвитку реабілітації та адаптації психічно хворих грає стигматизація. Огляд доповідей на тему стигматизація хотілося б почати 3 фрази, якій свою доповідь почав Wolfgang Gaebel: «Paніше, коли я починав розповідати про реабілітацію та стигматизації, слухачі починали залишати аудиторію, тепер, вони заходять». Відсутність підтримки і розуміння з боку суспільства, а часто «навіть відкрита дискримінація пацієнтів», зводить практично нанівець роботу, виконану сучасними лікарями. Наші пацієнти стикаються із зневажливим ставленням оточуючих, нерозумінням з боку родичів і колег, проблемами 3 працевлаштуванням, складнощами з отриманням грантів для перекваліфікації і т.д.

Wolfgang Gaebel запропонував розділити стигматизацію на декілька рівнів:

1. Культурна стигматизація являє собою дискримінаційне ставлення всього суспільства до психічно хворих і психіатрії у цілому, поява соціальних ярликів.

2. Інституційна стигматизація - законодавчо закріплена стигматизація.

3. Самостигматізація - стигматизація себе самого, з постійними думками про власну неповноцінність і неможливості стати активним членом суспільства $(<1>)$. Наслідком даної стигматизації є зниження самооцінки, погіршення адаптації та функціонування в суспільстві Цей вид стигматизації проходить кілька ступенів.

- Поінформованість про наявність стереотипів у суспільстві;

- Згода з правильністю даних стереотипів;

- Застосування їх до себе.

В основі боротьби з самостігматізаціей лежить розвиток автономності, можливість до самореалізації. Дані пацієнти потребують професійної підтримки як індивідуальної, так і в групах, яка дасть можливість сформувати впевненість в собі і виявити особистісні ресурси для подолання труднощів, пов'язаних з соціалізацією.

При розкритті теми стигматизації велику увагу було приділено не тільки стигматизації психічно хворих, а й стигматизації психіатрії в цілому і лікарів психіатрів зокрема. Практично в кожній доповіді зазначалося, що психіатрія «обросла» великою кількістю міфів, стереотипів, негативним ставленням суспільства ... Звичайно, дані стереотипи закріпились ще 3 «темних часів» психіатрії, коли у відсутності адекватного фармакологічного лікування, надія на допомогу фахівців була мінімальною і зводилася до ізоляції хворих. Потім був період «тільки седативних препаратів», коли вдавалося досягти тільки «млявості пацієнтів», а часто і неприємних побічних ефектів. Свій внесок у формування негативного ставлення сформували і фахівці психоаналізу і гіпнозу, які вели сеанси у своєрідній манері і створювали відчуття «величезної влади над пацієнтом». Крім того, до цих пір «людей лякає неповне розуміння того, що відбувається з хворим $(<2>)$. Вказані настрої в масах призвели до розвитку стигматизації психіатрії як професії. В даний час відзначається різка нестача фахівців у сфері психічного здоров'я. Студенти медичних факультетів не хочуть спеціалізуватися в області психіатрії, особливо великій психіатрії.

У представлених рекомендаціях по боротьбі з даними формами стигматизації, особливо в роботах «Іспанського Товариства психіатрів», рекомендовано було залучати родичів пацієнтів і самих пацієнтів для виступу в засобах масової інформації. Національні психіатричні спільноти повинні більше виступати в рамках психосвіти суспільства і всіма силами боротися зі стигматизацією душевно хворих пацієнтів. Так «Іспанська Спільнота психіатрів», «Іспанська спільнота біологічної психіатрії, «Іспанський фонд психіатрії і психічного здоров'я» відкрили новий рух: «Так психіатрії». В рамках даного руху були проведені акції з підвищення престижу цієї професії і дестигматизації психічних хворих. Відбулися шість групових зустрічей між психіатрами та спеціалістами інших медичних спеціальностей, одна зустріч психіатрів зі студентами, одна - 3 психологами, вісімнадцять - 3 пацієнтами та їх родинами, шість - 3 провідними журналістами, 2000 зустрічей - $з$ обивателями.

В ході опитування, що проводилося під час цих зустрічей, кожен другий опитаний повідомив, що серед його родичів є люди з тими чи іншими психологічними або психіатричними проблемами. За описом опитаних, можна припустити, що 48-53\% зазначених родичів мали психічний розлад, а близько $66 \%$ - тривожний або депресивний (Miquel Roca Bennasar президент «Испанского Фонда Психиатрии и Психического Здоровья») $(<\underline{3}>)$.Так в ході скринінгових опитувань було виявлено, що близько $25 \%$ осіб, які знали про наявність у них психічних розладів, не звернулися до фахівців охорони здоров'я. Більшість з тих, хто не звернувся за допомогою до лікарів мали фобії, компульсивні розлади, алкогольні, наркотичні та медикаментозні залежності.

В ході європейських та австралійських скринінгових опитувань, вдалося яскраво розглянути і ставлення суспільства до психіатрів, так $17 \%$ респондентів не вважають «психіатрів лікарями». Останнє місце в даному рейтингу зайняли дерматологи, психіатри розташувалися на рядок вище. Варто нагадати, що в групу опитуваних входили не тільки обивателі, а й артисти, журналісти, громадські діячі лікарі інших спеціальностей. $54 \%$ опитаних поставили престиж професії психіатра на останнє місце серед медичних спеціальностей $(<\underline{4}>)$.

Було виявлене негативне ставлення до людей, які налаштовані звернутися за допомогою або вже зверталися до психіатрів: так $23 \%$ респондентів, вважаю, що «ті, хто ходять до психіатрів - ненормальні». $26 \%$ респондентів повідомили про те, що вони мали нега- 
тивний досвід відвідування психіатрів, в тому числі і від того, що виникали складності в плані доступності консультації фахівців $(<4>)$. Часто опитані розповідали про свої страхи звернутися до фахівця через отриману від родичів і знайомих негативну інформації про психіатричну допомогу.

В рамках розробленої в Іспанії програми по дестигматизації психіатрії «Так психіатрії планується проведення щорічних конгресів спільних з фахівцями інших медичних профілів, відкриття спеціалізованих сайтів, висвітлення теми психічного здоров'я в засобах масової інформації, проведення «тижнів психічного здоров'я», виставок «Арт-терапії в психіатрії », проведення інформаційних семінарів в школах.

\section{3. Тяжкі психічні розлади - орієнтир на виду- жання}

Окрему категорію пацієнтів, витрати на лікування та реабілітацію яких особливо великі, становить група людей з тяжкими психічними розладами (ТПР). Визначити поширеність ТПР не просто, так як відмінності у визначенні дають різні цифри. Важко діагностувати ці стани серед особливих груп населення, наприклад, серед бездомних. Не можна забувати і про так звану «лікувальну прогалину» (gap) - різницею між тими, хто реально хворий і тими, хто звертається за допомогою. У своїй доповіді Thomas Becker представив дані системи охорони здоров'я Німеччини, він вказує, що у вибірці пацієнтів поширеність ТПР становить 1,6\%, а серед загального населення від 18 до 65 років дані поширеності коливаються від 2 до 4,1\%. Це означає, що тільки в Німеччині від 500 тисяч до 1 мільйона людей потребують комплексних інтервенцій в зв'язку з ТПР в системі охорони психічного здоров'я. За попередніми підрахунками приблизна поширеність ТПР становить 1-2\% загальної популяції $(<\underline{5}>)$.

До категорії тяжких психічних розладів відносять:

1. діагноз: важка депресія, шизофренія, інші психотичні розлади, біполярний афективний розлад (БАР), обсесивно-компульсивний розлад, посттравматичний стресовий розлад (ПТСР), тяжкий розлад особистості;

2. тривалість захворювання - як мінімум 2 роки;

3. за шкалою глобального функціонування (global assessment of functioning, GAF) - значна психосоціальна дезадаптація $(<\underline{6}>)$.

Шизофренія посідає лідируюче місце серед всіх інвалідизуючих захворювань, які призводять до втрати працездатності, зачіпає життя понад 25 мільйонів людей безпосередньо, і більше 50 мільйонів людей опосередковано, в зв'язку з негативним впливом на повсякденне життя пацієнта і його родичів. Але не дивлячись на минулий песимістичний погляд на шизофренію, як на хронічне захворювання, що приводить до деградації, почали з'являтися докази того, що люди з діагнозом шизофренія можуть мати хороший прогноз $(<7>)$. Ці дані підтверджуються довгостроковими дослідженнями, до $50 \%$ людей, які страждають на цю хворобу мають хороші прогнози (істотне зменшення симптомів, гарна якість життя і функціонування в суспільстві протягом тривалого періоду часу).

Хороший прогноз не означає одужання в класичному розумінні цього терміна (усунення або зменшення симптомів і повернення до преморбідного рівня функціонування, або відсутність хвороби, зцілення). Така концептуалізація може бути адекватною в разі гострих захворювань, таких як грип або перелом кістки, але не підходить для хронічних захворювань, таких як діабет, астма або шизофренія. В ході лонгітудинальних досліджень пацієнтів з ТПР основним критерієм для хорошого прогнозу дослідниками були визначені показники шкали GAF вище 61 балу: "деякі легкі симптоми ... або незначні труднощі в ряді областей функціонування, але в цілому функціонує досить добре ... і більшість людей не вважають його хворим" $(<\underline{8}>)$. Харроу і колеги проводили подібне дослідження з подальшим спостереженням протягом 15 років. Вони розробили більш докладне визначення хорошого результату хвороби, яке вимагає:

- період відсутності психотичних і негативних симптомів протягом 1 року;

- адекватне психосоціальне функціонування, в тому числі оплачувана робота (півставки або більше) i відсутність низького соціального рівня активності;

- відсутність психіатричних госпіталізацій протягом 5 років $(<\underline{9>})$.

Останнім часом зростає вплив суспільства споживачів на формування та зміну системи охорони здоров'я. Було виявлено зростання кількості споживачів серед людей, які страждають на шизофренію, які бачать традиційні служби охорони психічного здоров'я, як ятрогенні, які породжують відчуття безнадійності і безпорадності, які зміцнюють залежність, а також підсилюють стигму. Факт госпіталізації в гостре психотичні відділення може стати більш травмуючим ніж постановка психіатричного діагнозу. Пацієнти тривалий час перебувають в гострих відділеннях, що створює чергу на госпіталізацію для інших пацієнтів, або одна госпіталізація змінює іншу, що є економічно невигідно як для держави, так і для родичів. Якщо пацієнти потребують постійного спостереження, так як часто їх здатність самостійно себе обслуговувати знижена, родичі змушені оплачувати перебування в клініках, ще частіше у родичів виникає необхідність залишити роботу і здійснювати догляд, що також призводить до істотних витрат.

Helen Killaspy (London, United Kingdom) зазначила, на даний момент такі країни як Болгарія, Чехія, Німеччина, Італія, Нідерланди, Польща, Португалія, Іспанія 
i Великобританія ініціювали процес і знаходяться на різних стадіях деінстітуціоналізації $(<10>)$. Цей процес полягає в широкомасштабному скорочення числа психіатричних ліжок і психіатричних лікарень 3 паралельним розвитком різних форм позалікарняної допомоги для споживачів психіатричних послуг (альтернативні види допомоги за місцем проживання). Мета - запобігти розвитку госпіталізму, відрив від суспільства, обмеження прав пацієнта. В основі деінстітуціоналізаціі лежить прагнення зробити психіатричну допомогу більш гуманної та ефективної в медичному та фінансовому плані. На думку споживачів, система повинна бути доповнена, психіатри повинні сприяти появі почуттів надії і оптимізму, і бути в змозі дати споживачам свободу вибору, включати пацієнта і членів сім’ї в якості партнерів у процесі лікування, бути орієнтованими на хороший прогноз і одужання.

\section{4. Методи психосоціальної реабілітації, заснова- ні на доказовій медицині}

На сьогодення ефективна психосоціальна реабілітація ТПР заснована на даних доказової медицини, повинна стати комбінованої і включати:

- підтримуючу фармакотерапію;

• когнітивно-поведінкову психотерапію;

- тренінг соціальних навичок та навичок асертивної поведінки;

- взаємопідтримку;

- когнітивно-поведінкову психотерапію;

- лікування за місцем проживання;

- підтримку в працевлаштуванні;

- супровід в економічних та юридичних питаннях.

Thomas Becker стверджує, що дана стратегія може бути реалізована завдяки створенню і впровадженню багаторівневої системи реабілітаційних центрів і спільнот, так званої «соmmunity-based mental health care» - система охорони психічного здоров'я, заснованих на співтоваристві. Вона включає в себе «підтримуюче проживання» 3 повним або частковим наглядом за місцем проживання, психіатричні відділення загальносоматических клінік, в тому числі денний стаціонар, медичні центри надання первинної допомоги, денні центри (клуби), центри-комуни, групи самодопомоги для пацієнтів з психічними порушеннями.

Альтернативні види допомоги за місцем проживання - це новий підхід в психосоціальної реабілітації, де пацієнти з ТПР проживають спільно, в робочі години відвідують тренінги соціальних навичок, отримують консультації з приводу працевлаштування, юридичну, економічну супровід, працюють з залежною поведінкою і все це в одному місці, назва якого підтримує
Рис. 1: Інтервенції в системі психіатричної допомоги в співтовариствах

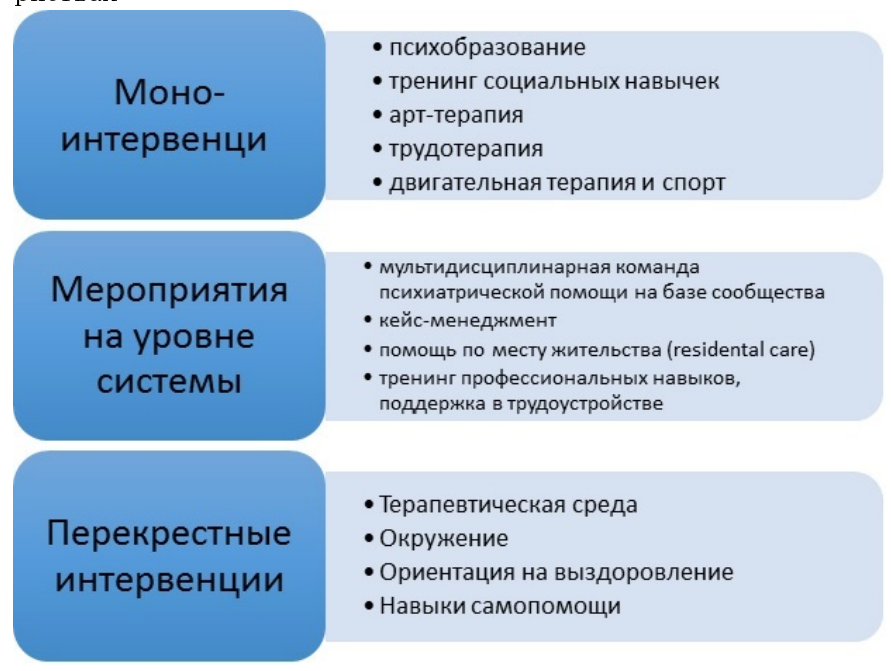

Служби, в основі яких лежить співтовариство, оперують різного рівня інтервенціями і системним підходом у відновленні психічного здоров'я, за допомогою надання належної підтримки і допомоги. Вони прагнуть максимізувати якість життя і соціальну включеність індивіда, розвиваючи соціальні навички комунікації, посилюючи незалежність і автономність, з метою дати надію на майбутне, яке веде до успішного життя в суспільстві

проживання - «supportive housing» $(<9>)$. Це особлива модель реабілітації домашнього типу, свого роду комуна - квартира або житловий простір для пацієнтів, яке містить система охорони здоров'я. Мультидисциплінарна команда фахівців допомагає пацієнтам підтримувати їх клінічну стабільність, функціонування, а також надає можливість здобувати нові навички самодопомоги. Пацієнти можуть перебувати в таких будинках цілодобово (residential care), це так звана кризова резиденція, у міру стабілізації психічного стану та поліпшення функціонування пацієнти можуть переходити на режим денного відвідування, далі пересуватися в резиденції з супервайзерами, пізніше - резиденції відкритого типу (пацієнт живе самостійно, звертається за допомогою при необхідності) <11>). Т. Becker в своїй доповіді представив порівняльні відмінності нового і старого підходу в організації психіатричної допомоги (Табл. 1).

Служби, в основі яких лежить співтовариство, оперують різного рівня інтервенціями (Рисунок 1) і системним підходом у відновленні психічного здоров'я, за допомогою надання належної підтримки і допомоги. Вони прагнуть максимізувати якість життя і соціальну включеність індивіда, розвиваючи соціальні навички комунікації, посилюючи незалежність і автономність, з метою дати надію на майбутнє, яке веде до успішного життя в суспільстві $(<12>)$.

Було проведено кілька ретроспективних досліджень, присвячених відстроченим результатам в динаміці психічного стану пацієнтів з ТПР, такими як шизофренія, шізоаффектівное розлад, БАР $(\mathrm{n}=141)$, які 
Табл. 1: Відмінності старого та нового підходу в психосоціальній реабілітації

\begin{tabular}{|c|c|}
\hline Стара парадигма & Нова парадигма \\
\hline \hline Тимчасове розмыщення & "Дім" \\
\hline Роль пацієнта & Звичні соціальні ролі \\
\hline Роль персоналу / лікар, медсестра & Контроль здійснюється клінєтами \\
\hline Об’єднання пацієнтів за ступенем інвалідності & Соціальна інтеграція, без розділення \\
\hline Проміжні підготовчі відділення & Навчання в звичних умовах \\
\hline Стандартизований сервіс & Клієнт-центрований гнучкий підхід, орієнтований на індивідуальні потреби (завдяки кейс-менеджменту) \\
\hline Стандартизований сервіс & Клієнт-центрований гнучкий підхід, орієнтований на індивідуальні потреби (завдяки кейс-менеджменту) \\
\hline Найменш обмежуюче середовище, незалежність & Найбільш пілтримуюче середовище \\
\hline \hline
\end{tabular}

зверталися за допомогою і тривалий час спостерігалися в центрах або службах психіатричної реабілітації заснованих на співтовариствах. Через 5 років у $67 \%$ пацієнтів спостерігався позитивний результат: 40\% звернулися до центрів і співтовариства підтримки з великим рівнем незалежності, $27 \%$ залишилися на тому ж рівні підтримуваного проживання. Негативний результат оцінювався у разі, якщо пацієнт був госпіталізований в гостре психіатричне відділення або продовжував потребувати постійному спостереженні і перебування в реабілітаційному центрі, тобто ступінь автономності знизилася у $38 \%$ пацієнтів, що було асоційоване з низькою прихильністю до медикаментозної терапії $(<10>)$.

Огляд рандомізованих контрольованих досліджень, метою яких було визначити ефект програм підтримуючого проживання (ПП) в порівнянні з програмами соціальної підтримки за місцем проживання (ПСП) і стандартної психіатричною допомогою (СП).

- ПП - автономне проживання в спеціальному будинку, персонал надає професійну підтримку, доступний в робочі години;

- ПСП - автономне проживання, окреме від інших пацієнтів з важкими психічними захворюваннями (на відміну від ПП) професійний персонал здійснює щоденні візити додому;

- СП - стандартна психіатрична допомога.

Показники ефективності, які оцінювалися в ході дослідження: 1) психічний стан, 2) доступність сервісу, 3) задоволеність наданою допомогою 4) соціальне функціонування (інтеграція в суспільство) 5) якість життя, 6) показники економічної вигідності. Вибір схеми лікування здійснювався особистим вибором пацієнта, професійною думкою, доступністю ресурсів. Результат - ПП надає сприятливий ефект, рівень задоволення середній-високий, підтримує стабільний рівень психічного стану, призводить до скорочення госпіталізацій і фінансових витрат $(<\underline{13}>)$.

\section{5. Роль сім’і в процесі реабілітації}

У своїй доповіді Bert Johnson (Leuven, Belgium) президент асоціації родичів людей з психічними розладами зазначив, що в сумі їх чисельність становить 25 мільйонів сімей по всій Європі (<14>). В ході презентації він наголосив, що сім'я повинна відігравати виняткову роль в системі охорони психічного здоров'я, але на практиці це не завжди в достатній мірі усвідомлюється. Реабілітація часто найбільш вимоглива і відповідальна частина процесу. Оплата послуг реабілітаційних центрів може стає непосильною ношею для родичів пацієнтів. I тоді рідні беруть на себе цю функцію. Родичі перевіряють, чи приймається призначене лікування регулярно, надають місце проживання, тим самим перешкоджаючи бездомності, беруть на себе піклування та надають важливу і правдиву інформацію відповідальним професіоналам. I в той же час вони можуть піддаватися найсильнішому емоційному стресу, наражати на небезпеку своє здоров'я і благополуччя, відчувати на собі ефекти стигматизації і відповідно потребують підтримки та розуміння, а також спеціального навчання, як бути поруч із психічно тяжко хворою людиною.

Від психіатричних служб родичам необхідно отримувати в письмовій та усній, доступною для розуміння, інформацію про:

- діагностику та лікування психозу та шизофренії;

- способах попередження загострення;

- позитивних результатах лікування та одужання;

- можливостях підтримки для осіб, які здійснюють догляд;

- отримання допомоги в кризовій ситуації.

\section{6. Арт терапія - терапія творчістю, що нового?}

У доповіді, присвяченій методам психосоціальної реабілітації, заснованих на доказовій медицині, було представлено цікаве дослідження MATISSE (мультицентровое дослідження арт-терапії при шизофренії, систематична оцінка), яке показало, що в ході застосування арт-терапії (малювання) у пацієнтів з шизофренією (n=417) у відділеннях реабілітації, в групі арт-терапії (n=140, щотижневі зустрічі, 90 хвилин, 12 місяців з метою поліпшити здатність до експресії, емоційний стан і функціонування) в порівнянні з стандартним психотропним лікуванням $(\mathrm{n}=137)$ і групою активного контролю (n=140, спільні активності - кіно, кафе, ігри) не було виявлено значних переваг у порівнянні 3 іншими групами. Аналіз відсутності переваг арт-терапії 
показав, майже $40 \%$ спроб провести групові сесії зазнали краху, спостерігався низький рівень прихильності, а також у пацієнтів був відсутній ресурс приймати такого роду інтервенції. Докази ефективності підтримуючої арт-терапії з часом все ж зростають, але як і раніше залишаються помірним.

В одному з досліджень ефективності терапії творчістю проводилося порівняння між арт-терапією (малювання), драма-терапією, танцювально-рухової терапією і музичною терапією. З'ясувалося, що завдяки сеансам музичної терапії у пацієнтів з шизофренією поліпшується загальне благополуччя, функціонування в суспільстві, знижується депресивна симптоматика і тривога, а також зменшуються прояви негативних симптомів даного захворювання, якщо кількість сеансів перевищує $20(<15>)$.

Музикотерапія - психотерапевтичний метод, який звертається до внутрішньо- і інтерпсихічному, а також зачіпає соціальні процеси, використовуючи музичну взаємодію як спосіб комунікації, експресії і перетворення. Завдання терапії - за допомогою музики допомогти людям з серйозними психічними порушеннями вибудувати відносини з терапевтом, що б в подальшому дати можливість вирішувати проблеми, які вони не в змозі висловити тільки словами. Музична терапія може відрізнятися за модальністю ( «активна» роль, або «рецептивна»), рівню структури, увазі на музиці як такої, або на словесній обробці музичних переживань, викликаних музикою. Активна модальність включає в себе всі види діяльності, де клієнтам пропонують грати музикальні композиції або співати, вільно імпровізувати, писати пісень. Рецептивні методи пропонують слухати музику; терапевт може грати для клієнта, або для прослуховування вибираються музичні записи, в подальшому йде дискусія або рефлексія почуттів, що виникли під час роботи. Деякі моделі музичної терапії використовують один режим музичної взаємодії, але більшість - комбінують різні підходи. Існують структуровані форми музикування або більш гнучкі схеми, коли структура визначається в діалозі з клієнтом. Можливі індивідуальні зустрічі або робота в невеликих групах. Таким чином, ефективність музичної терапії для людей з ТПР в значній мірі залежить від кількості сеансів, регулярності участі, протягом тривалого часу (не менше 20 сесій), а також якості музичної терапії (сертифіковані музичні терапевти, використання адекватних методів музичної терапії). Активна участь має вирішальне значення для успіху музичної терапії. Учасникам не потрібні музичні спеціальні навички, але мотивація активно працювати в рамках процесу музичної терапії має дуже важливе значення.

\section{7. Чи ефективна когнітивно-поведінкова тера- пія при психозах?}

В настанові Національного інституту здоров'я, Великобританія, когнітивно-біхевіоріальна терапія (КБТ) при психозах включена в якості бажаної терапї $(<16>)$. 3 цієї тези розпочав свою доповідь, присвячену психосоціальним інтервенцій при шизофренії, Til Wykes (London, United Kingdom) ( $<17>)$. Якщо людина має підвищений ризик розвитку психозу, то йому рекомендовано пройти курс КБТ з або без сімейної терапії. КБТ при психозах має розширені цілі: позитивні, негативні симптоми, мислення і пам'ять, ставлення до лікування / прийому медикаментів, соціальне i професійне функціонування, рівень самооцінки, самоефективність, стійкість до стресів, самостигматизація, коморбідні симптоми (тривога, депресія, ПТСР, вживання ПАР), якість життя, соціальна інтеграція.

В першу чергу, як показує мета-аналіз, КБТ благотворно впливає на позитивні симптоми: зниження кількості і інтенсивності маячних ідей, зниження загальної стурбованості $(<18>)$. Така психотерапевтична подорож прагне полегшити дистрес, викликаний позитивними симптомами, зазвичай триває близько 20 сесій (6-9 місяців). В ній терапевт і клієнт об'єднують сили для того, щоб ідентифікувати переконання клієнта, які обмежують досягнення особистих цілей, терапевт супроводжує клієнта в переоцінці цінностей минулого досвіду , спільно визначаються нові способи поведінки. Але насправді, не дивлячись на те, що керівництво рекомендує КБТ при психозах, і зокрема при шизофренії, тільки 1 з 10 пацієнтів реально отримує терапію.

Незалежне опитування в клініці PiCKUP (Maudsley) показало - практичні лікарі, пацієнти і члени їх сімей вважають, що на додачу до фармакотерапії важливі такі інтервенції:

- КБТ - $43 \%$;

- взаємодопомога - 34\%;

- виконання запропонованих вправ - $22 \%$;

- сімейна терапія - 20\%;

3'являється все більше інформації, що впровадження взаємодопомоги і взаємопідтримки серед пацієнтів з ТПР, також позитивно впливає на варіативні показники, які відносяться до процесу одужання. Взаємодопомога надається кваліфікованим працівником, який пройшов професійну підготовку для роботи в реабілітаційних програмах, і має, або мав діагноз шизофренія / психотичний розлад, але знаходиться в стабільній ремісії тривалий час.

Підпорядкування імперативним галюцинацій при психозах може мати серйозні наслідки, як для людини, так і для інших людей, і є однією з основних причин громадського неспокою у зв'язку з ТПР. Психотерапевтичних інтервенцій, заснованих на доказовій медицині і здатних зменшити таку поведінку, довгий час не існувало. Завдяки проведеним рандомізованих контрольованих досліджень (COMMAND - Cognitive behaviour therapy to prevent harmful compliance with command hallucinations, 2014 року) вдалося порівняти 
результати когнітивно-поведінкової терапії для запобігання згубного підпорядкування імперативним галюцинацій в поєднанні з стандартним медикаментозним лікуванням, з групою контролю (стандартне лікування) $(<19>)$. У когнітивній терапії при імперативних галюцинаціях методи КБТ використовуються для зміни переконань / установок, пов'язаних з владою, яку пацієнти приписують голосам:

- Голос має абсолютну владу та контроль.

- Індивід повинен підкоритись, догоджати або бути суворо покараним.

- Ідентичність голосу (наприклад, Диявол).

- Значення, яке надається голосу (наприклад, фізична особа карає за минулий проступок).

Новий підхід в когнітивній терапії був орієнтований на те, щоб кинути виклик силі і влади голосу, які сприймає пацієнь; у відповідь на імперативи заподіяти шкоду собі або іншим підвищити здатність пацієнта опиратися, знизити мотивацію на виконання команди. Через 18 місяців спостереження, 46\% (n=39) з 85 учасників групи стандартного лікування, мали принаймні один епізод повного підпорядкування імперативів в порівнянні з 28\% (n=22) з 79 пацієнтів у групі когнітивної терапії + стандартне лікування. Отже, когнітивна терапія для запобігання згубного підпорядкування імперативним галюцинацій в поєднанні з стандартним лікуванням надає статистично і клінічно значимий і більший вплив на зниження темпів підпорядкування імперативним галюцинацій в порівнянні зі стандартними схемами лікування (відносний ризик 0,$45 ; \mathrm{p}=0,021$ ).

Психотичні симптоми є досить поширеним явищем в загальній популяції. Особи, у яких нещодавно виникли психозоподібні симптоми, але субпсихотичної інтенсивності, схильні до підвищеного ризику прогресування до повного психозу протягом декількох років. Такі продромальні випадки показують нейрокогнітівний дефіцит, аналогічний тому, який спостерігаються при першому нападі шизофренії. Більш високі бали позитивних симптомів сильно впливають на когнітивні функції, відповідно можливість впливати і коригувати когнітивні функції є бажаним ефектом і стає ще однією важливою метою КБТ. Однією з ефективних стратегій психосоціальної реабілітації при шизофренії є когнітивна корекційна терапія (KKT), вона використовує науковий підхід в навчанні, впливаючи на когнітивний дефіцит з метою поліпшити увагу, пам'ять, виконавчі функції, рівень щоденного функціонування. Метааналіз проведений в 2011 році включав дані 1982 учасника, розмір ефекту KKT на когнітивні функції 0,45, на загальний показник функціонування - 0,40, симптоми $0,18(<\underline{20>}>)$.

Такий тренінг зазвичай включає інтенсивну практику повторення, безпомилковий тренінг (Знижує помилки, збільшує акуратність), вербальний моніторинг, поступове збільшення навантаження (покращує виконання) $<21>$ ). КKT в поєднанні $з$ тренінгом соціальних навичок дає значне поліпшення когнітивних функцій в загальному, комунікативних та професійних навичках зокрема $(<22>)$, а в поєднанні з підтримкою в працевлаштуванні дозволяє уникнути провалу при прийомі на роботу $(<23>)$.

Аналіз досліджень комп'ютеризованої когнітивної корекційної терапії показав суперечливі результати в різних країнах, поліпшення результатів зазначалося тільки протягом сесії та було відсутнє після закінчення участі в тренінгу.

ВПТ в комбінації з соціально-орієнтованими програмами ассертивної підтримки для неаффектівних психозів показала свою ефективність щодо зниження інтенсивності симптомів, за шкалою PANSS; F $(1,69)$ $=3,99, \mathrm{p}=0,005$, а також поліпшення повсякденної активності $(<24>)$. Команда ассертивної підтримки працює з людьми, які старші 18 років, мають складні потреби (жорстока, агресивна, саморуйнівна поведінка, відсутність реакції на лікування, вживання ПАР, подвійний діагноз, схильність до бродяжництва) і потребують більш активної підтримки. Такі команди надають допомогу в наступному вигляді:

- в повсякденному житті, покупки в магазині, складання бюджету, приготування їжі та прибирання;

• контроль прийому медикаментів;

- контроль вживання наркотиків/алкоголю;

- допомога в участі життя суспільства, якщо пацієнт ізольований;

- поліпшення фізичного здоров'я;

- підтримка в пошуку відповідної освіти, працевлаштування та навчання;

- підтримка в пошуку житла;

- розробка плану щодо «профілактики рецидиву», увага на тригери, які можуть призводити до загострення хвороби;

- розробка антикризового плану, в ситуації погіршення стану.

\section{8. Чи працює психотерапія без психотерапевта?}

У продовженні своєї доповіді Til Wykes (London, United Kingdom) торкнулася актуального питання: як інтернет і цифрові технології можуть допомагати (або ні) в лікуванні психічних розладів? Зацікавленість у відповіді зростає пропорційно розвитку сфери IT. Основною причиною стимулу до розвитку даного напрямку є припущення, що впровадження даних послуг 
дозволить знизити зростаючі витрати на охорону здоров'я. Останнім часом все більшу поширеність набувають різного роду мобільні додатки і онлайн програми психоосвіти (містять відповіді на найпоширеніші питання), модеровані форуми, соціальні мережі для пацієнтів з ТПР (взаємодопомога, питання експертам), інтегрована інтернет терапія, додатки для мобільних телефонів . Але варто звернути увагу, що з 5000 різних додатків тільки 5 пройшли попередній контроль якості і їх ефективність була доведена $(\langle 25\rangle)$. Серед типових додатків 3 доведеною ефективністю $є$ такі, які регулярно нагадують приймати медикаменти. Особливий інтерес представляє програма «Аватар-терапія». У ній задіяні пацієнт, терапевт і аватар (створений в програмі образ відповідний зоровим, слуховим галюцинацій пацієнта). Відповідно, коли пацієнт вибирає зоровий образ, тембр голосу, міміку і повадки, проектуючи внутрішні переживання на аватар, зростає його контроль і влада не тільки над аватаром, а й над голосами, що, в свою чергу, підвищує самооцінку, сприяє зростанні критики до стану. Образ аватара може змінюватися відповідно до змін у психічному стані, таким чином пацієнт отримує «терапевта в кишені». Існують докази, що дана інтервенція знижує всесилля голосів і рівень жорстокого поводження $(<26>)$. Схожим ефектом може володіти когнітивна терапія на базі віртуальної реальності $(<27>)$.

\section{9. Висновок}

В даному огляді ми ставили за мету показати, що психосоціальна реабілітація при важких психічних розладах працює. Чим раніше, тим ефективніше. Комплексний підхід довів свою ефективність (дві інтервенції краще ніж одна). Але стигматизація, як і раніше, в значній мірі перегороджує надання реабілітаційної допомоги пацієнтам з ТПР. Проте, психологічне лікування здатне підвищити соціальну інтеграцію, задоволеність лікуванням, прихильності до терапії і самодопомоги, викликає поліпшення окремих симптомів, скорочує кількість і тривалість госпіталізацій, і що не менш важливо - не має побічних ефектів. Головне завдання психосоціальної реабілітації - бути орієнтованою на одужання. Одужання - це розвиток нових сенсів і цілей в житті, всупереч катастрофічного ефекту психічного захворювання, це можливість мати надію в майбутньому побудувати щось нове.

\section{References}

1. Gaebel W, Evans-Lacko U. Promotion Stigma Coping and Empowerment: Results from the Multi- Center Clinical Trial STEM. Florence, Italy: 25th European Congress of Psychiatry; 2016.

2. Stuart H. Fighting the stigma caused by mental disorders: past perspectives, present activities, and future directions. World Psychiatry 2008;7(3):185-8. doi 10.1002/j.2051-5545.2008. tb00194.x
3. Bennasar MR. Campaigning against Stigma in Spain. Florence, Italy: 25th European Congress of Psychiatry; 2016.

4. Hoopwood M. An antipodean Multicultural View of stigma: Fear, Prejudice or Discrimination? Florence, Italy: 25th European Congress of Psychiatry; 2016.

5. Becker T, Guhne U, Riedel-Heller T. Evidence-based psychosocial measures in rehabilitation. Symposium: psychosocial rehabilitation and mental health. Florence, Italy: 25th European Congress of Psychiatry; 2016.

6. Hauth I. Die Arbeitssituation von Menschen mit schweren psychischen Erkrankungen in Deutschland. DGPPN; 2015.

7. Bellack A. Scientific and consumer models of recovery in schizophrenia: Concordance, contrasts, and implications. Schizophr Bull 2006;32(3):432-42.

8. Harding C, Brooks G, Ashikaga T, Strauss J, Breier A. The vermont longitudinal study of persons with severe mental illness, i: methodology, study sample, and overall status 32 years later. Schizophrenia Bulletin 2006;144(6):718-26.

9. Harrow M, Grossman L, Jobe T, Herbener E. Do patients with schizophrenia ever show periods of recovery? a 15-year multi-follow-up study. Schizophrenia Bulletin 2005;31(3):72334. doi $10.1093 / \mathrm{schbul} / \mathrm{sbi026}$.

10. Killaspy H. Quality assessment of mental heath rehabilitation services. Symposium: psychosocial rehabilitation and mental health. Florence, Italy: 25th European Congress of Psychiatry; 2016.

11. Ridgway P, Ziple A. The paradigm shift in residential services: From the linear continuum to supported housing approaches. Psychosocial Rehabilitation Journal 1990;13(4):11-31. doi 10 . $1037 / \mathrm{h} 0099479$

12. Doughty C, Tse S. Can consumer-led mental health services be equally effective? an integrative review of clmh services in highincome countries. Community Ment Health J 2011;47(3):25266. doi 10.1007/s10597-010-9321-5

13. Chilvers R, Macdonald G, Hayes A. Supported housing for people with severe mental disorders. Cochrane Database Syst Rev 2006;4:CD000453. doi 10.1002/14651858.CD000453.pub2.

14. Johnson B. Families and their roles in the rehabilitation process. Symposium: psychosocial rehabilitation and mental health. Florence, Italy: 25th European Congress of Psychiatry; 2016.

15. Mössler K, Chen X, Heldal T, Gold C. Music therapy for people with schizophrenia and schizophrenia-like disorders. Cochrane Database Syst Rev 2011;12:CD004025. doi 10.1002/14651858. CD004025.pub35

16. Psychosis and schizophrenia in adults: prevention and management. Clinical guideline[CG178]. United Kingdom: National Institute for Health and Care Excellence; 2014.

17. Wykes T. Psychosocial intervention in schizophrenia. Florence, Italy: 25th European Congress of Psychiatry; 2016.

18. Wykes T, Steel C, Everitt B, Tarrier N. Cognitive behavior therapy for schizophrenia: effect sizes, clinical models, and methodological rigor. Schizophr Bull 2008;34(3):523-37. doi $10.1093 / \mathrm{schbul} / \mathrm{sbm} 114$

19. Birchwood M, Birchwood M. Cognitive behavior therapy to prevent harmful compliance with command hallucinations (command): a randomized controlled trial. Lancet Psychiatry 2014;1(1):23-33. doi $10.1016 /$ S2215-0366(14)70247-0

20. Wykes T, Huddy V, Cellard C. A meta-analysis of cognitive remediation for schizophrenia: methodology and effect sizes. $A m$ J Psychiatry 2011;168(5):472-85. doi 10.1176/appi.ajp.2010. 10060855 .

21. Wykes T, Reeder C, Landau S, Everitt B, Knapp M, Patel A, Romeo R. A meta-analysis of cognitive remediation for schizophrenia: methodology and effect sizes. The British Journal of Psychiatry 2007;190(5):421-7. doi 10.1192/bjp.bp.106. 026575

22. Bowie C, McGurk S, Mausbach B, Patterson T, Harvey P. Combined cognitive remediation and functional skills training for schizophrenia: effects on cognition, functional competence, and real-world behavior. Am J Psychiatry 2012;169(7):710-8. 
23. McGurk S, Mueser K, Xie H, Welsh J, Kaiser S. Cognitive enhancement treatment for people with mental illness who do not respond to supported employment: a randomized controlled trial. Am J Psychiatry 2015;172(9):852-61.

24. Fowler D, Hodgekins J, Painter M, Reilly T, Crane C. Cognitive behaviour therapy for improving social recovery in psychosis: a report from the isrep mrc trial platform study (improving social recovery in early psychosis). Psychological Medicine 2009;39(10):1627-36.

25. Wykes T, Brown M. Over promised, over-sold and underperforming? - e-health in mental health. Am J Psychiatry 2016;25(1):1-4. doi 10.3109/09638237.2015.1124406

26. Leff J, Williams G, Huckvale M, Arbunthnot M, Leff A. Computer-assisted therapy for medication-resistant auditory hallucinations: proof-of-concept study. The British Journal of Psychiatry 2013;202(6):428-33. doi 10.1192/bjp.bp.112. 124883

27. Valmaggia L, Latif L, Kempton M, Rus-Calafell M. Virtual reality in the psychological treatment for mental health problems: An systematic review of recent evidence. Psychiatry Research 2016;236:189-95. doi 10.1016/j.psychres.2016.01. 015 